\title{
Risk Factors of anemia in head and neck cancer patients undergoing chemotherapy with high-dose cisplatin
}

\author{
Johan Kurnianda ${ }^{1}$, Nugroho Wiyadi ${ }^{2}$, Wahyu Wulaningsih ${ }^{3}$
}

\begin{abstract}
Abstrak
Anemia merupakan salah satu efek samping yang paling sering dialami pasien kanker yang diterapi dengan cisplatin dosis tinggi. Penelitian ini bertujuan untuk mengamati perkembangan anemia dan menentukan faktor-faktor yang berpengaruh terhadap anemia pada pasien yang diterapi cisplatin. Dilakukan pengumpulan data pada pasien kanker kepala dan leher yang menjalani kemoterapi berbasis cisplatin antara Desember 2002 hingga Desember 2005. Insidensi dan faktor risiko anemia dianalisis dengan mencakup faktor usia, jenis kelamin, kadar Hb awal, klirens kreatinin awal, dan metastasis jauh. Stratifikasi menurut usia dan jenis kelamin dilakukan terhadap kadar $\mathrm{Hb}$ awal dan $\mathrm{CrCl}$ awal. Analisis multivariat digunakan untuk mengidentifikasi prediktor independen anemia. Dari 86 pasien, 26 (30,2\%) mengalami anemia, ditandai kadar hemoglobin $<11 \mathrm{~g} / \mathrm{dL}$. Kadar hemoglobin turun secara signifikan setelah siklus pertama, dan terus menurun. Usia $>55$ tahun $(R R=2.2,95 \%$ CI, 1.2-4.0), jenis kelamin perempuan (RR $=2.0,95 \%$ CI, 1.2-3.8), $\mathrm{kadar}$ $\mathrm{Hb}$ awal $\leq 13 \mathrm{~g} / \mathrm{dL}(\mathrm{RR}=4.2,95 \% \mathrm{CI}, 1.9-9.4)$ dan $\mathrm{CrCl}$ awal $<50 \mathrm{~mL} / \mathrm{menit}(\mathrm{RR}=2.9,95 \%$ CI, 1.7-5.1) berkorelasi dengan insidensi anemia $(P<0.05)$. Pada analisis multivariat, kadar hemoglobin awal dan klirens kreatinin awal merupakan faktor risiko independen anemia. Akan tetapi, terdapat efek perancu pada klirens kreatinin awal pada stratifikasi menurut usia (aRR = 2.2, 95\% CI, 1.1-4.7). Kadar hemoglobin awal merupakan prediktor terkuat dari anemia. Kadar hemoglobin awal $\leq 13 \mathrm{~g} / \mathrm{dL}$ ke bawah dan klirens kreatinin awal $<50 \mathrm{~g} / \mathrm{dL}$ merupakan prediktor independen anemia akibat cisplatin, sehingga keduanya bernilai penting terhadap upaya prevensi anemia. (Med J Indones 2008; 17: 248-54)
\end{abstract}

\begin{abstract}
s
Cisplatin is well-known for its effectiveness against cancer, as well as its toxicity to human tissues. Of several documented side effects, anemia was reported to have significant association with decreased quality of life. This study was conducted to investigate development of cisplatin-induced anemia, and to identify independent factors contributing to anemia. Clinical data from head and neck cancer patients treated with high-dose cisplatin between December 2002 and December 2005 were obtained in this study. Incidence and risk factors of anemia were assessed in a model including age, sex, baseline hemoglobin level, baseline creatinine clearance, and occurrence of distant metastases. Multivariate logistic regression was used to define independent predictors of anemia. Among 86 eligible patients, 26 (30.2\%) developed anemia, defined as Hb level lower than $11 \mathrm{~g} / \mathrm{dL}$. Age $>55$ years old $(R R=2.2,95 \%$ CI, 1.2-4.0), female sex (RR $=2.0$, $95 \%$ CI, 1.2-3.8), baseline $\mathrm{Hb} \leq 13 \mathrm{~g} / \mathrm{dL}(\mathrm{RR}=4.2,95 \% \mathrm{CI}, 1.9-9.4)$ and baseline $\mathrm{CrCl}<50 \mathrm{~mL} / \mathrm{min}(\mathrm{RR}=2.9,95 \% \mathrm{CI}, 1.7-5.1)$ were significantly correlated with incidence of anemia $(P<0.05)$. In multivariate analysis, baseline $\mathrm{Hb}$ and baseline $\mathrm{CrCl}$ were identified as independent risk factors for anemia. However, considerable confounding was observed in baseline CrCl after stratified by age (aRR = 2.2, 95\% CI, 1.1-4.7). Thus, baseline Hb level was the strongest predictor of anemia. The findings suggested that baseline Hb and CrCl were useful to recognize cisplatin-treated patients at risk for anemia who might benefits from preventive measures. (Med J Indones 2008; 17: 248-54)
\end{abstract}

Keywords: anemia, cisplatin, chemotherapy, hemoglobin, creatinine clearance

1 Division of Hematology-Oncology, Department of Internal Medicine, Faculty of Medicine, Sardjito Hospital, Gadjah Mada University, Jogjakarta, Indonesia

2 Department of Public Health, Faculty of Medicine, Gadjah Mada University, Jogjakarta, Indonesia

3 Faculty of Medicine, Gadjah Mada University, Jogjakarta,

Indonesia
Anemia is one of the most frequent side effects experienced by cancer patients undergoing chemotherapy with cisplatin. ${ }^{1}$ Severe ciplatin-induced anemia correlates significantly with decreased overall survival and reduced quality of life. ${ }^{2,3}$ Several patients will need blood transfusions to correct their anemia. ${ }^{4}$ 
In cancer patients, hemoglobin level declined proggressively after administration of cisplatin, but medullary erythroblastic cellularity was reported normal. ${ }^{5}$ Decline of hemoglobin level correlates with decrease of creatinine clearance, indicating an association between the development of anemia and deterioration of kidney tubular function. Those findings implied the etiology of cisplatin-induced anemia as an erythropoietin deficiency state secondary to cisplatin-induced nephrotoxicity. ${ }^{6,7}$

Erythropoietin administration is able to correct the resultant anemia and increase quality of life. However, $20-40 \%$ patients still need to be transfused. ${ }^{8-9}$ Therefore, the use of erythropoietin as a preventive measure, i.e. erythropoietin administration to patients at high risk of developing anemia during chemotherapy, was considered at higher value. Identification of high-risk patients is essential to attain cost-effective measures. Besides, identification of anemia risk factors in patients undergoing chemotherapy with cisplatin has a prognostic value for the need of blood transfusions in near future. ${ }^{2}$

Previous studies have defined several factors contributing in development of anemia in chemotherapy patients, ${ }^{10,11}$ but there is still lack of evidence providing risk adjustment for potential confounding comorbid. The present study aims to investigate the development of anemia in patients treated with cisplatin-based chemotherapy, as well as to analize in a comprehensive fashion the interaction between factors contributing to the risk of anemia, and to define independent risks of cisplatin-induced anemia.

\section{METHODS}

This study included 86 nasopharyngeal cancer patients admitted to Oncology Unit, Sardjito Hospital, Jogjakarta, Indonesia between December 2002 and December 2005. Data was obtained from two previous studies conducted in Sardjito Hospital. ${ }^{12,13}$ There were 139 subjects at initial selection, 135 among them have evaluable clinical data. Only 91 patients completing at least three chemotherapy courses were included in the study. Among them, 86 subjects met the inclusion criteria, i.e. patients who did not have anemia at the beginning of chemotherapy, defined as hemoglobin level less than $11 \mathrm{~g} / \mathrm{dL}$. Their characteristics are shown in table 1.
Table 1. Characteristics of patients*

\begin{tabular}{|c|c|c|c|}
\hline \multicolumn{2}{|c|}{ Characteristics } & No. of Patients & $\%$ \\
\hline \multicolumn{4}{|l|}{ Age (years) } \\
\hline Median & 43.5 & & \\
\hline Range & $15-67$ & & \\
\hline$\leq 55$ & & 69 & 80.2 \\
\hline$>55$ & & 17 & 19.8 \\
\hline \multicolumn{4}{|l|}{ Sex } \\
\hline \multicolumn{2}{|l|}{ Female } & 18 & 20.9 \\
\hline \multicolumn{2}{|l|}{ Male } & 68 & 79.1 \\
\hline \multicolumn{4}{|l|}{ Regimen } \\
\hline \multicolumn{2}{|c|}{ Gemcitabine-Cisplatin } & 24 & 27.9 \\
\hline \multicolumn{2}{|c|}{ Cisplatin-5-Fluorouracil } & 62 & 72.1 \\
\hline \multicolumn{4}{|c|}{ Cancer staging } \\
\hline \multicolumn{2}{|c|}{ II } & 1 & 1.2 \\
\hline \multicolumn{2}{|l|}{ III } & 21 & 24.4 \\
\hline \multicolumn{2}{|c|}{ IV } & 64 & 74.4 \\
\hline \multicolumn{4}{|c|}{ Distant metastases } \\
\hline \multicolumn{2}{|c|}{ Yes } & 9 & 10.5 \\
\hline \multicolumn{2}{|l|}{ No } & 77 & 89.5 \\
\hline \multicolumn{4}{|c|}{ Baseline $\mathrm{Hb}^{*}$ level $(\mathrm{g} / \mathrm{dL})$} \\
\hline Mean & 13.3 & & \\
\hline$\pm \mathrm{SD}$ & 1.4 & & \\
\hline \multicolumn{2}{|l|}{$\leq 13$} & 38 & 44.2 \\
\hline \multicolumn{2}{|c|}{$>13$} & 48 & 55.8 \\
\hline \multicolumn{4}{|c|}{ Baseline $\mathrm{CrCl}^{*}(\mathrm{~mL} / \mathrm{min})$} \\
\hline Mean & 70.6 & & \\
\hline$\pm \mathrm{SD}$ & 20.1 & & \\
\hline$<50$ & & 8 & 9.3 \\
\hline$\geq 50$ & & 78 & 90.7 \\
\hline
\end{tabular}

$* \mathrm{Hb}=$ hemoglobin; $\mathrm{CrCl}=$ creatinine clearance

Two regimens containing high-dose cisplatin, i.e. single dose more than $50 \mathrm{mg} / \mathrm{m}^{2}$, were included in this study. Those regimens are gemcitabine-cisplatin and cisplatin5-fluorouracil. A cycle of gemcitabine-cisplatin regimen consisted of administration of cisplatin intravenously in $80 \mathrm{mg} / \mathrm{m}^{2}$ dose on day 1 , and gemcitabine $1250 \mathrm{mg} / \mathrm{m}^{2}$ was given on day 1 and 8 every 3 weeks. ${ }^{12}$ In cisplatin$5 \mathrm{FU}$ regimen, cisplatin was given in $100 \mathrm{mg} / \mathrm{m}^{2}$ dose on day 1 , and $5 \mathrm{FU}$ was given on day 1 and 5 every 3 weeks. ${ }^{13}$

In this cohort study, ${ }^{14}$ patients' data were obtained from a case report form of two previous studies conducted in Sardjito Hospital, Jogjakarta, Indonesia. The outcome was incidence of anemia, defined as decrease in blood hemoglobin to a level less than $11 \mathrm{~g} / \mathrm{dL}$ on any course among the first three observed. Every patient was only counted once. Considered as exposures were age $>55$ years old, female sex, baseline hemoglobin level $\leq 13$ $\mathrm{g} / \mathrm{dL}$, and baseline creatinine clearance $<50 \mathrm{~mL} / \mathrm{min}$. Creatinine clearance was estimated according to the Cockroft-Gault formula for creatinine clearance. ${ }^{15}$ 
Data was analyzed with EpiInfo version 6. Hemoglobin level was observed in every cycle, and paired t-test was used to determine the significant decline in mean hemoglobin levels. Univariate analysis for anemia risk factors was performed with chi $^{2}$ test. To eliminate confounding factors, baseline hemoglobin level and baseline creatinine clearance level were stratified for patients' age and sex, using Mantel Haenszel chi test. A multivariate logistic regression was performed to define independent predictors of anemia. P value $<0.05$ was considered significant.

\section{RESULTS}

At the beginning of chemotherapy, all patients have hemoglobin level above $11 \mathrm{~g} / \mathrm{dL}$, therefore no anemia was observed. After first course, $8(9.3 \%)$ patients became anemic, no moderate-severe anemia according to WHO classification, i.e. hemoglobin level $<9.5 \mathrm{~g} / \mathrm{dL}$, was observed. Hence either incidence and prevalence on first cycle was $9.3 \%$. Prevalence of anemia increased on second course $(17.4 \%)$ and third course $(27.9 \%)$. Moderate-severe anemia was experienced by $3(3.5 \%)$ patients on second course, and $5(5.8 \%)$ patients on third course of chemotherapy. Overall incidence of anemia during three chemotherapy courses was $26(30.2 \%)$. Of 26 patients, $9(34.6 \%)$ had onset of anemia on third course, $9(34.6 \%)$ on the second. Thus incidence of anemia in this study was $9.3 \%$ on first course, $11.5 \%$ on second course, and $13.1 \%$ on third course. Prevalence and incidence of anemia are shown in figure 1 .

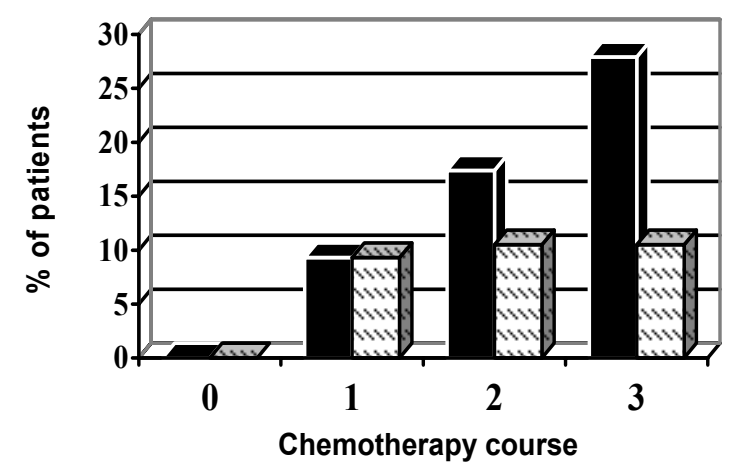

- Prevalence of anemia $\quad$ Incidence of anemia

Figure 1. Prevalence and incidence of anemia in patients undergoing chemotherapy with high-dose cisplatin. At initial encounter, none of the patient was anemic, defined as hemoglobin level less than 11 $g / d L$. The incidence and prevalence of anemia rose proggressively after first course of cisplatin-based chemotherapy.
To understand the development of anemia, the alterations of mean hemoglobin levels before and after every chemotherapy course were observed. Paired t-test results are shown in table 2. Before chemotherapy, mean hemoglobin level was $13.3 \mathrm{~g} / \mathrm{dL}$, with the range of 11.0 to $16.6 \mathrm{~g} / \mathrm{dL}$. This level decline accumulatively during subsequent courses, as shown in figure 2 . Overall decrease was significant $(\mathrm{P}<0.001)$ with a difference $1.55 \mathrm{~g} / \mathrm{dL}$ from baseline level. Decrease of hemoglobin was significant for course 1,2, and 3, with most prominent decline on first course, which differed $0.75 \mathrm{~g} / \mathrm{dL}$ from baseline.

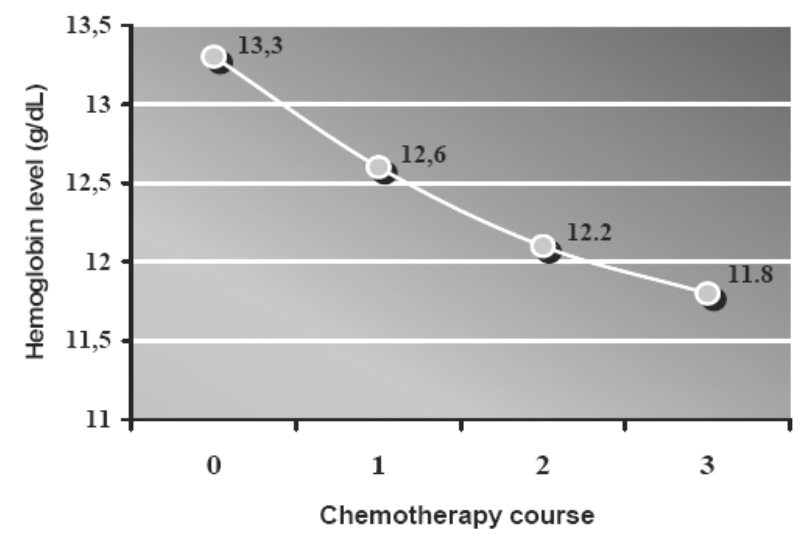

Figure 2. Mean hemoglobin levels before chemotherapy and after each course of chemotherapy observed (1st, 2nd, and 3rd course). There was a significant decrease overall and after every course of chemotherapy with cisplatin. Greatest hemoglobin decline was observed after first course of chemotherapy with cisplatin.

Table 2. Hemoglobin levels before and during chemotherapy*

\begin{tabular}{cccccc}
\hline \multirow{2}{*}{$\begin{array}{c}\text { Chemotherapy } \\
\text { course }\end{array}$} & Mean & $\pm \mathrm{SD}$ & Range & $\begin{array}{c}\mathrm{Hb} \\
\text { decline }\end{array}$ & $\mathrm{P}^{\dagger}$ \\
\cline { 2 - 6 } & & & & & \\
\hline $\begin{array}{c}\text { Pre chemo- } \\
\text { therapy }\end{array}$ & 13,3 & 1,38 & $11,0-16,6$ & - & - \\
1 & 12,6 & 1,36 & $9,6-15,9$ & 0,75 & $<0,001$ \\
2 & 12,2 & 1,36 & $8,8-14,7$ & 0,39 & 0,002 \\
3 & 11,8 & 1,72 & $6,7-17,0$ & 0,41 & 0,003 \\
\hline
\end{tabular}

* $\mathrm{Hb}=$ hemoglobin; $\mathrm{Hb}$ decline was calculated by substracting hemoglobin level of previous course with hemoglobin level of the next course.

$\uparrow$ Significant for $\mathrm{P}$ value $<0,05$

From univariate analysis results as shown in table 3, age $>55$ years old $(\mathrm{RR}=2.2,95 \% \mathrm{CI}, 1.2-4.0)$, female sex $(\mathrm{RR}=2.0,95 \% \mathrm{CI}, 1.2-3.8)$, baseline $\mathrm{Hb}$ level $\leq 13 \mathrm{~g} / \mathrm{dL}(\mathrm{RR}=4.2,95 \% \mathrm{CI}, 1.9-9.4)$ and baseline $\mathrm{CrCl}<50 \mathrm{~mL} /$ menit $(\mathrm{RR}=2.9,95 \% \mathrm{CI}, 1.7-5.1)$ have 
significant correlation with the incidence of anemia $(\mathrm{P}<0.05)$. $\mathrm{P}$ value was not significant $(>0,05)$ for presence of distant metastases in this study.

Age and sex were well-known as factors associated with baseline hemoglobin and baseline creatinine clearance. ${ }^{16,17}$ Therefore, stratification was performed on baseline hemoglobin level and baseline creatinine clearance for patients' age and sex to eliminate confounding effects and to calculate the actual risk. The results are shown in table 4 .

Table 3. Univariate analysis for risk factors of cisplatin-induced anemia*

\begin{tabular}{|c|c|c|c|c|c|c|}
\hline \multirow{2}{*}{ Risk Factors } & \multicolumn{2}{|c|}{ Patients } & \multicolumn{2}{|c|}{ Anemia } & \multirow{2}{*}{$\mathrm{X}^{2}$} & \multirow{2}{*}{$\mathrm{p}^{\dagger}$} \\
\hline & $\mathrm{n}$ & $\%$ & $\mathrm{n}$ & $\%$ & & \\
\hline Age & & & & & 5.18 & 0.023 \\
\hline$\leq 55$ years old & 69 & 80.2 & 17 & 24.6 & & \\
\hline$>55$ years old & 17 & 19.8 & 9 & 52.9 & & \\
\hline Sex & & & & & 4.22 & 0.04 \\
\hline Female & 18 & 20.9 & 9 & 50.0 & & \\
\hline Male & 68 & 79.1 & 17 & 25.0 & & \\
\hline Baseline $\mathrm{Hb}$ level & & & & & 16.19 & $<0.001$ \\
\hline$\leq 13 \mathrm{~g} / \mathrm{dL}$ & 38 & 44.2 & 20 & 52.6 & & \\
\hline$>13 \mathrm{~g} / \mathrm{dL}$ & 48 & 55.8 & 6 & 12.5 & & \\
\hline Baseline $\mathrm{CrCl}$ & & & & & 6.33 & 0.008 \\
\hline$<50 \mathrm{~mL} / \mathrm{min}$ & 8 & 9.3 & 6 & 75.0 & & \\
\hline$\geq 50 \mathrm{~mL} / \mathrm{min}$ & 78 & 90.7 & 20 & 25.6 & & \\
\hline Distant metastases & & & & & 0.31 & 0.71 \\
\hline Yes & 9 & 10.5 & 2 & 22.2 & & \\
\hline No & 77 & 89.5 & 24 & 31.2 & & \\
\hline
\end{tabular}

* Anemia was defined as $\mathrm{Hb}<11 \mathrm{~g} / \mathrm{dL} . \mathrm{Hb}=$ hemoglobin; $\mathrm{CrCl}=$ creatinine clearance.

Table 4. Stratification analysis for risk factors of cisplatin-induced anemia*

\begin{tabular}{|c|c|c|c|}
\hline Variables & Crude RR $(95 \% \mathrm{CI})$ & Adjusted RR (95\% CI) & $\mathrm{p}^{\dagger}$ \\
\hline \multicolumn{4}{|l|}{ Age } \\
\hline Baseline Hb level & & & $<0.001$ \\
\hline$\leq 13 \mathrm{~g} / \mathrm{dL}$ & $4.2(1.9-9.4)$ & $4.1(1.9-8.9)$ & \\
\hline$>13 \mathrm{~g} / \mathrm{dL}$ & 1 & 1 & \\
\hline Baseline $\mathrm{CrCl}$ & & & 0.059 \\
\hline$<50 \mathrm{~mL} / \mathrm{min}$ & $2.9(1.7-5.1)$ & $2.2(1.1-4.7)$ & \\
\hline$\geq 50 \mathrm{~mL} / \mathrm{min}$ & 1 & 1 & \\
\hline \multicolumn{4}{|l|}{ Sex } \\
\hline Baseline $\mathrm{Hb}$ level & & & $<0.001$ \\
\hline$\leq 13 \mathrm{~g} / \mathrm{dL}$ & $4.2(1.9-9.4)$ & $4.3(1.7-11.0)$ & \\
\hline$>13 \mathrm{~g} / \mathrm{dL}$ & 1 & 1 & \\
\hline Baseline $\mathrm{CrCl}$ & & & 0.015 \\
\hline$<50 \mathrm{~mL} / \mathrm{min}$ & $2.9(1.7-5.1)$ & $2.6(1.5-4.4)$ & \\
\hline$\geq 50 \mathrm{~mL} / \mathrm{min}$ & 1 & 1 & \\
\hline
\end{tabular}

* Baseline $\mathrm{Hb}$ level = baseline hemoglobin level; baseline $\mathrm{CrCl}$ = baseline creatinine clearance; $\mathrm{RR}=$ relative risk; a value of 1 is a reference. 
On stratification based on patients' sex, baseline creatinine clearance less than $50 \mathrm{~mL} / \mathrm{min}$ still significantly correlated with the risk of anemia, however, there is a difference in risk calculated after stratification, implying some degree of confounding. On stratification based on patients' age, there was a substantial confounding observed, indicated by more than $10 \%$ difference between adjusted risk and the initially calculated risk, thus the correlation between baseline creatinine clearance with incidence of anemia became insignificant. Patients' age and sex confound the relationship between baseline creatinine clearance and incidence of anemia, therefore baseline creatinine clearance less than $50 \mathrm{~mL} / \mathrm{min}$ was a weak risk factor for cisplatin-induced anemia.

In multivariate analysis as shown in table 5, among age, sex, baseline hemoglobin level and baseline creatinine clearance, only two were recognized as independent risk factors of anemia, those were baseline hemoglobin level $13 \mathrm{~g} / \mathrm{dL}$ and less $(\mathrm{P}<0.001)$ and baseline creatinine clearance less than $50 \mathrm{~mL} / \mathrm{min}(\mathrm{P}<0.05)$. Baseline hemoglobin level $\leq 13 \mathrm{~g} / \mathrm{dL}$ was the strongest risk factor for cisplatin-induced anemia.

Table 5. Multivariate analysis for risk factors of cisplatin-induced anemia

\begin{tabular}{|c|c|c|c|}
\hline Risk Factors & $\begin{array}{c}\text { Crude OR } \\
(95 \% \mathrm{CI})\end{array}$ & $\begin{array}{l}\text { Adjusted OR } \\
\quad(95 \% \mathrm{CI})\end{array}$ & $\mathrm{P}^{\dagger}$ \\
\hline $\begin{array}{l}\text { Age } \\
\qquad 55 \text { years old } \\
\leq 55 \text { years old }\end{array}$ & $\begin{array}{c}3.4(1.1-10.3) \\
1\end{array}$ & $\begin{array}{c}2.5(0.6-10.6) \\
1\end{array}$ & 0.204 \\
\hline $\begin{array}{l}\text { Sex } \\
\quad \text { Female } \\
\quad \text { Male }\end{array}$ & $\begin{array}{c}3.0(1.0-8.8) \\
1\end{array}$ & $\begin{array}{c}1.7(0.5-6.0) \\
1\end{array}$ & 0.441 \\
\hline $\begin{array}{l}\text { Baseline Hb level } \\
\quad \leq 13 \mathrm{~g} / \mathrm{dL} \\
>13 \mathrm{~g} / \mathrm{dL}\end{array}$ & $\begin{array}{c}7.8(2.7-22.6) \\
1\end{array}$ & $\begin{array}{c}9.6(2.7-33.3) \\
1\end{array}$ & $<0.001$ \\
\hline $\begin{array}{l}\text { Baseline } \mathrm{CrCl} \\
\quad<50 \mathrm{~mL} / \mathrm{min} \\
\quad \geq 50 \mathrm{~mL} / \mathrm{min}\end{array}$ & $\begin{array}{c}5.7(1.3-25.0) \\
1\end{array}$ & $\begin{array}{c}9.0(1.1-73.6) \\
1\end{array}$ & 0.041 \\
\hline $\begin{array}{l}* \text { Baseline } \mathrm{Hb} \text { leve } \\
=\text { baseline creati } \\
\text { is a reference. }\end{array}$ & $\begin{array}{l}\text { baseline hem } \\
\text { e clearance; }\end{array}$ & $\begin{array}{l}\text { globin level; ba } \\
\mathrm{R}=\text { odds ratio; }\end{array}$ & $\begin{array}{l}\text { eline } \mathrm{CrCl} \\
\text { value of } 1\end{array}$ \\
\hline
\end{tabular}

\section{DISCUSSION}

This study was intended to identify risk factors of cisplatin-induced anemia. In univariate analysis, age $>55$ years old, female sex, baseline hemoglobin level $\leq 13 \mathrm{~g} / \mathrm{dL}$, and baseline creatinine level $<50 \mathrm{~mL} / \mathrm{min}$ were correlated significantly with incidence of anemia. Occurrence of distant metastases was not significantly correlated with anemia. This finding is similar to previous study which stated that metastases did not have significant correlation with nadir of hemoglobin post chemotherapy with cisplatin ${ }^{10}$. On the other side, a recent study ${ }^{16}$ mentioned that occurrence of metastases was an independent risk factors of severe anemia on patients treated with cytotoxic chemotherapy (OR $=2.8 ; 95 \% \mathrm{CI}=1.2-7.1)$. Those difference may be caused by different characteristics of subjects included. In this study, the most prominent decline of hemoglobin occurred after first course of chemotherapy, while in previous study, hemoglobin level fell most markedly after third course of cisplatin-based chemotherapy. ${ }^{6}$

Baseline hemoglobin level $13 \mathrm{~g} / \mathrm{dL}$ and less was reported to correlate with risks of severe chemotherapyassociated anemia. ${ }^{16}$ Similar finding was noted in this study, where hemoglobin level $\leq 13 \mathrm{~g} / \mathrm{dL}$ was defined as risk factor for anemia ( $\mathrm{RR}=4.2 ; 95 \% \mathrm{CI}=1.9-9.4)$. Several other studies also establish baseline hemoglobin level as risk factor for anemia with different cutoffs, such as hemoglobin level less than $12 \mathrm{~g} / \mathrm{dL}^{18}$ and low normal hemoglobin level, i.e. 12.0-13.4 g/dL for male and $12.0-12.9 \mathrm{~g} / \mathrm{dL}$ for female, ${ }^{19}$ as independent risk factor of chemotherapy-induced anemia.

Patients with age older than 55 years have greater risk of developing anemia $(\mathrm{RR}=2.2 ; 95 \% \mathrm{CI}=1.2-4.0)$. The results confirmed that advanced age was a risk factor for cisplatin-induced anemia, as stated by some previous studies. In a study evaluating risk factors of cisplatin-associated anemia, ${ }^{10}$ it was reported that the nadir of hemoglobin throughout chemotherapy with cisplatin was significantly lower in patients with age older than 60 years old $(\mathrm{P}<0.05)$, while in National Health And Nutrition Examination Survey III (NHANES III), prevalence of anemia is significantly higher in age population more than 65 years old. ${ }^{20}$ Another study ${ }^{18}$ reported no association between severe anemia requiring transfusions (SAART) with age in patients undergoing cytotoxic chemotherapy.

In recent study about risk factors of chemotherapyinduced anemia, ${ }^{18}$ female sex was reported to have 
significant correlation with severe anemia $(\mathrm{P}<0.05)$, but was not identified as independent risk factor. The present study has similar finding, female sex was correlated with anemia $(\mathrm{RR}=2.0 ; 95 \% \mathrm{CI}=1.1-3.8)$ but was not an independent predictor in multivariate analysis. Another study observed no significant relationship between sex and nadir of hemoglobin after first course of chemotherapy with cisplatin. ${ }^{10}$

Baseline creatinine clearance less than $50 \mathrm{~mL} / \mathrm{min}$ was correlated significantly with incidence of anemia $(\mathrm{RR}=2.9 ; 95 \% \mathrm{CI}=1.7-5.1)$. As a comparison, from the data obtained through NHANES III survey, it was reported $^{16}$ that at creatinine clearance level below 50 $\mathrm{mL} / \mathrm{min}$, a significant decreace in hemoglobin level was observed in both males and females, only in males this fall of hemoglobin level started at creatinine clearance level less than $70 \mathrm{~mL} / \mathrm{min}$. This finding suggested a correlation between sex and baseline creatinine clearance as risk factor of anemia.

In regards of previous studies reporting a relationship between age and sex with baseline hemoglobin level and baseline creatinine clearance, ${ }^{16,17}$ stratification analysis were performed to eliminate confounding factors. As the results, both age and sex of patients have confounding effects towards the correlations between baseline hemoglobin level with anemia, and baseline creatinine clearance with anemia as well. For baseline hemoglobin, confounding were only slightly observed, that the adjusted risk calculated was not notably different from initial risk $(\mathrm{aRR}=4.1 ; 95 \% \mathrm{CI}=1.7-10.0)$ and the correlation with anemia remained significant $(\mathrm{P}<$ $0.001)$. In contrast, adjusted risk for baseline creatinine clearance was considerably lower than initial risk (aRR $=2.7 ; 95 \% \mathrm{CI}=1.0-7.6)$ that the correlation with anemia became insignificant $(\mathrm{P}>0.05)$. This implied creatinine clearance as a weak risk factor.

In multivariate analysis with logistic regression, only baseline hemoglobin level $\leq 13 \mathrm{~g} / \mathrm{dL}(\mathrm{OR}=9 ., 6 ; 95 \%$ $\mathrm{CI}=2.7-33.3)$ and baseline creatinine clearance $<50$ $\mathrm{mL} / \mathrm{min}(\mathrm{OR}=9.0 ; 95 \% \mathrm{CI}=1.1-73.6)$ were identified as independent predictors, with baseline hemoglobin level as predominant risk factor $(\mathrm{P}<0.001)$. These results were equivalent with prior findings ${ }^{10}$ that reported baseline hemoglobin level as independent predictor of nadir of hemoglobin after first course of cisplatin-based chemotherapy, and the recent cohort ${ }^{11}$ that denoted baseline hemoglobin level less than 13 $\mathrm{g} / \mathrm{dL}$ as independent risk factor of chemotherapy- associated anemia ( $\mathrm{OR}=0.55 ; 95 \%$ CI $0.39-0.77)$. With different cutoffs, other study also reported that hemoglobin level was identified as independent risk factor of severe anemia following chemotherapy $(\mathrm{OR}=$ $14.0 ; 95 \% \mathrm{CI}=7.0-30.0)$. A recent survey in Australia ${ }^{19}$ also stated that low normal hemoglobin level was a risk factor of anemia in chemoterapy patients $(\mathrm{OR}=5.4$; $95 \% \mathrm{CI}=2.7-10.9)$.

Most recent study indicated that maintenance of hemoglobin level between 11 to $12 \mathrm{mg} / \mathrm{dL}$ is significantly correlated with increased quality of life in cancer patients. ${ }^{21}$ This finding gave rise to preventive efforts in order to maintain the level of hemoglobin in desired range. Identification of risk factors is thereby important for high-risk patients who would benefit most from prophylaxis for anemia. ${ }^{9}$

There were limitations in this study, such as the predicted value instead of measured actual creatinine clearance, the elimination of risk from both combining cytotoxic agents and dose difference, and the definition of anemia that was limited to decrease of hemoglobin level instead of patients' functional state. For consideration, earlier study reported that there was a significant correlation between the rise of hemoglobin level and improvement of quality of life in cancer patients, ${ }^{22}$ hence identification of risk factor of anemia will indirectly promote the preservation of quality of life by maintaining hemoglobin level in desired range, i.e. above $11 \mathrm{~g} / \mathrm{dL}{ }^{21}$

It is concluded that hemoglobin level in cancer patients undergoing cisplatin-based chemotherapy fell significantly after first course of chemotherapy, and continue to decrease afterward. Baseline hemoglobin level of $13 \mathrm{~g} / \mathrm{dL}$ and less and baseline creatinine clearance less than $50 \mathrm{~mL} / \mathrm{min}$ are independent predictors of cisplatin-induced anemia. These findings suggest that both hemoglobin level and creatinine clearance are useful to recognize high-risk patients who might need specific treatment for anemia in the future. By contrary, prevention of cisplatin-induced anemia may be accomplished by modifying these baseline characteristic of patients. However, futher studies are needed to establish particular management of cisplatinbased anemia based on individual risk assessment.

\section{REFERENCES}

1. Miller CB, Platanias LC, Mills SR, Zahurak ML, Ratain MJ, Ettinger JS, et al. Phase I-II trial of erythropoietin in 
the treatment of cisplatin-associated anemia. J Natl Cancer Inst 1992; 84: 98-103.

2. Groopman JE, Itri LM. Chemotherapy-induced anemia in adults: Incidence and treatment. J Natl Cancer Inst 1999; 91: 1616-34.

3. Pivot X, Guardiola E, Etienne M, Thyss A, Foa C, Otto J, et al. An analysis of potential factors allowing an individual prediction of cisplatin-induced anaemia [abstract]. Eur J Cancer 2000; 36: 852-7.

4. Locatelli MC, Tedeschi L, Clerici M, Romanelli A, D'Antona A, Labianca $R$, et al. Cisplatin-associated anaemia in patients with solid tumours: A retrospective evaluation and considerations relative to erythropoietin administration. Support Care Cancer 1996; 4: 218-9.

5. Dufour P, Bergerat JP, Eber M, Renaud P, Karcher V, Giron $\mathrm{C}$, et al. Cisplatin-induced anemia: a potential interference with iron metabolism at erythroid progenitors level [abstract]. Anticancer Drugs 1990; 1: 49-54.

6. Wood PA, Hrushesky WJM. Cisplatin-associated anemia: An erythropoietin deficiency syndrome. J Clin Invest 1995; 95: $1650-9$

7. Lee SJ, Kwon JH, Jung CW. Erythropoietin response is inadequate in cancer patients receiving chemotherapy. Int J Hematol 2001; 74: 416-20.

8. Chu E, Einhorn LH, Lefebvre P. Clinical benefits of onceweekly epoetin alfa in anemic patients with colorectal cancer receiving chemotherapy. J Support Oncol 2006; 4: 243-50.

9. Del Mastro L, Venturini M. Strategies for the use of epoetin alfa in breast cancer patients. The Oncologist 1998; 3: 314-8.

10. Okamoto H, Saijo N, Shinkai T, Eguchi K, Sasaki Y, Tamura $\mathrm{T}$, et al. Chemotherapy-induced anemia in patients with primary lung cancer [abstract]. Annl Oncol 1992; 3: 819-24.

11. Juan O, Albert A, Almenar D, Olmos S, Vidal J, Molins C, et al. Risk model for severe anemia in patients with nonhematologic cancer receiving conventional chemotherapy: Results from a multicenter prospective cohort study [abstract]. J Clin Oncol 2005; 23(Pt.I): 8121.

12. Mann CJ. Observational research methods. Research design II: cohort, cross sectional, and case-control studies. Emerg Med J 2003; 20: 54-60.
13. Kurnianda J, Pardjono E, Adiwijono A, et al. Combination of gemcitabine and cisplatin (GC) chemotherapy for advanced or recurrent nasopharyngeal cancer (NPC): A phase II study. J Clin Oncol 2004; 22(14 Suppl): 5577. Presented on the 2004 ASCO Annual Meeting, New Orleans, 2004.

14. Widayati K, Kurnianda J, Purwanto I, et al. Evaluation of nasopharyngeal cancer neoadjuvant standing treatment protocol 4 cycles of cisplatin-5 FU followed by EBRT at dr Sardjito Hospital Yogyakarta Indonesia. Presented on the East West Symposium on Nasopharyngeal Cancer, Toronto, June 16-18, 2005.

15. Cockcroft DW, Gault MH. Prediction of creatinine clearance from serum creatinine. Nephron 1976; 16: 31-41.

16. Hsu CY, McCulloch CE, Curhan GC. Epidemiology of anemia associated with chronic renal insufficiency among adults in the United States: Results from the Third National Health and Nutrition Examination Survey. J Am Soc Nephrol 2002; 13: 504-10.

17. Guralnik JM, Eisenstaedt RS, Ferrucci L, et al. Prevalence of anemia in persons 65 years and older in the United States: Evidence for a high rate of unexplained anemia. Blood 2004; 104: 2263-8.

18. Ray-Coquard I, Le Cesne A, Rubio MT, et al. Risk model for severe anemia requiring red blood cell transfusion after cytotoxic conventional chemotherapy regimens. J Clin Oncol 1999; 17: 2840-6.

19. Seshadri T, Prince HM, Bell DR, et al The Australian Cancer Anaemia Survey: A snapshot of anaemia in adult patients with cancer. MJA 2005; 182: 453-7.

20. Balducci L. Anemia, cancer, and aging. Cancer Control 2003; 10: 478-86.

21. NCCN Clinical Practice Guidelines in Oncology: Cancerand Treatment-Related Anemia [monograph online]. Rodgers GM, Cella D, Chanan-Khan A, et al. National Comprehensive Cancer Network, Inc, producers. Version 2.2006. Utah: NCCN; 2006 [cited 2006 Dec 15]. Available from: URL:http://www.ncen.org.

22. N, Triaspolitica. "Mengenal Penyakit Kanker, Jenis, Gejala, Penyebab Berikut Pengobatan Kanker." Mau Nanya Dong Dok. N.p, 20 June 2017. Web. 28 June 2017. $<$ https://nanyadongdok.blogspot.com/2017/06/mengenalpenyakit-kangker-jenis-gejala.html $>$. 